\title{
Komposisi Jenis Vegetasi Penyusun Hutan Mangrove Di Desa Nipah Panjang Kabupaten Kubu Raya
}

\author{
Widiya Octa Selfiany \\ Fakultas Pertanian Universitas Kapuas Sintang \\ Email: widiya211@gmail.com
}

\begin{abstract}
Abstrak: Penelitian ini bertujuan untuk memperoleh informasi tentang keanekaragaman jenis vegetasi hutan mangrove di Desa Nipah Panjang Kabupaten Kubu Raya. Analisi indeks nilai penting (INP), indeks dominansi (C), indeks kekayaan spesies (RI), indeks kemerataan jenis (E) dilakukan menggunakan menggunakan metode survey dengan cara jalur berpetak. Peletakan jalur penelitian dilakukan dengan metode purposive sistematik sampling. Jumlah jalur yang dibuat sebanyak 5 jalur penelitian dengan jarak antar jalur $500 \mathrm{~m}$. Di dalam jalur penelitian dibuat petak ukuran $10 \times 10 \mathrm{~m}$ (tingkat pohon), petak $5 \times 5$ $\mathrm{m}$ (tingkat pancang), dan 2 × $2 \mathrm{~m}$ (tingkat semai). Hasil penelitian menunjukkan bahwa hutan mangrove di Desa Nipah Panjang tergolong normal. Jumlah jenis vegetasi yang ditemukan tingkat semai berjumlah 8 jenis dengan jumlah individu 11.100/ha, tingkat pancang 7 jenis dengan jumlah individu 2.288/ha dan tingkat pohon 8 jenis dengan jumlah individu 530/ha. INP tertinggi tingkat semai jenis Rhizophora mucronata dengan nilai INP sebesar 41,94\%, pada tingkat pertumbuhan pancang nilai INP tertinggi adalah jenis Sonneratia alba dengan nilai INP sebesar 52,83\% dan pada tingkat pertumbuhan pohon nilai INP tertinggi terdapat pada jenis Bruguiera gymnorrhiza dengan nilai INP sebesar 91,39\%. Nilai keanekaragaman jenis hutan mangrove Desa Nipah Panjang tergolong sedang dengan kemerataan tidak merata dan kekayaan jenis tergolong rendah.
\end{abstract}

Kata Kunci : Komposisi Jenis Vegetasi, Hutan Mangrove

\section{PENDAHULUAN}

Indonesia memiliki hutan mangrove mencapai 3.489.140,68 ha, sementara sekitar 1.817.999,93 ha atau $52,10 \%$ dalam keadaan rusak (KLHK, 2017). Kerusakan hutan mangrove yang terjadi di Indonesia disebabkan oleh faktor alam dan faktor manusia. Penyebab faktor manusia terutama disebabkan oleh penebangan pohon, alih fungsi lahan untuk pembuatan tambak, dan lain sebagainya. Hutan mangrove merupakan istilah yang dipakai untuk menggambarkan suatu komunitas vegetasi pantai tropik yang didominasi oleh beberapa speseies pohon-pohon yang khas atau semak-semak yang mempunyai emampuan untuk tumbuh dalam perairan asin (Suryono, 2013).

Menurut Rahmawati et al, (2014) Hutan mangrove memiliki peran penting karena letak dan kondisinya yang strategis berada di 
Komposisi Jenis Vegetasi Penyusun Hutan Mangrove

Di Desa Nipah Panjang Kabupaten Kubu Raya

pinggir pantai dan menghadap

langsung ke laut, sehingga hutan mangrove berperan sebagai ekosistem penyanggah (buffer zone). Hasil penelitian Prastomo et al. (2017) jumlah jenis yang ditemukan di kawasan hutan mangrove desa Nusapati kabupaten Mempawah berjumlah 11 jenis, diantaranya yaitu: A. floridium, A. alba, A. lanata, A. marina, B. cylindrica, B. gymnorrhza, B.mparviflora, $E$. agallocha, S. alba, S. caseolaris, X. mollucensis.

Desa Nipah Panjang Kabupaten Kubu Raya memiliki hutan mangrove, namun informasi mengenai komposisi jenis vegetasi penyusun hutan mangrove di Desa Nipah Panjang belum tersedia. Dari hal tersebut di atas, sehingga dirasa perlu dilakukan penelitian mengenai komposisi jenis vegetasi penyusun hutan mangrove di Desa Nipah Panjang Kabupaten Kubu Raya.

\section{METODE PENELITIAN}

Penelitian ini dilakukan selama tiga minggu di lapangan. Metode yang digunakan dalam penelitian ini menggunakan metode survey dengan cara jalur berpetak. Penentuan jalur contoh penelitian dilakukan dengan cara purposive sistematik sampling. Jumlah jalur yang dibuat sebanyak 5 jalur penelitian dengan jarak antar jalur 500 m. Panjang jalur penelitian dibuat sepanjang $100 \mathrm{~m}$ dengan lebar 10 meter (5 m ke kiri $5 \mathrm{~m}$ ke kanan). Di dalam jalur penelitian dibuat sub-petak contoh ukuran 10 x $10 \mathrm{~m}$ (tingkat pohon), petak $5 \times 5 \mathrm{~m}$ (tingkat pancang), dan $2 \times 2 \mathrm{~m}$ (tingkat semai).

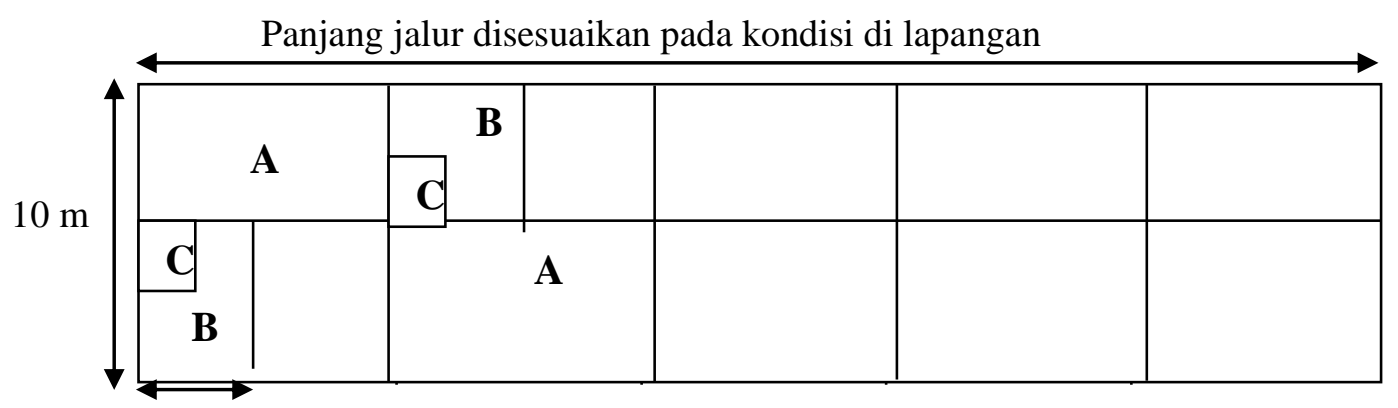

$5 \mathrm{~m}$

Gambar 1. Desain petak contoh di lapangan dengan metode jalur berpetak

Keterangan:

Petak $\mathrm{A}=$ petak berukuran $10 \mathrm{~m} \times 10 \mathrm{~m}$ untuk pengamatan tingkat pohon

Petak $\mathrm{B}=$ petak berukuran $5 \mathrm{~m} \times 5 \mathrm{~m}$ untuk pengamatan tingkat pancang

Petak $\mathrm{C}=$ petak berukuran $2 \mathrm{~m} \times 2 \mathrm{~m}$ untuk pengamatan tingkat semai 
1. Indeks Nilai Penting (Indriyanto, 2006):

Tingkat semai $=(\mathrm{INP}=\mathrm{KR}+\mathrm{FR})$

Tingkat pancang dan tingkat pohon $=(\mathrm{INP}=\mathrm{KR}+\mathrm{FR}+\mathrm{DR})$

1) Densitas/Kerapatan (K)

$\mathrm{K}-\mathrm{i}=\frac{\text { Jumlah Individu untuk spesies ke-i }}{\text { luas seluruh petak contoh }}$

2) Kerapatan relatif $(\mathrm{KR})$

$\mathrm{KR}-\mathrm{i}=\frac{\text { Kerapatan spesies ke-i }}{\text { Kerapatan seluruh spesies }} \times 100 \%$

3) Frekuensi (F)

$\mathrm{F}-\mathrm{i}=\frac{\text { Jumlah petak contoh ditemukannya suatu spesies ke-i }}{\text { Jumlah seluruh petak contoh }}$

4) Frekuensi Relatif (FR)

$\mathrm{FR}-\mathrm{i}=\frac{\text { Frekuensi suatu spesies ke-i }}{\text { Frekuensi seluruh spesies }} \times 100 \%$

5) Dominasi (D)

$\mathrm{D}-\mathrm{i}=\frac{\text { Luas bidang dasar suatu spesies }}{\text { Luas petak contoh keseluiruhan }}$

6) Dominasi Relatif (DR)

$\mathrm{DR}-\mathrm{I}=\frac{\text { Dominasi suatu spesies }}{\text { Dominasi total seluruh spesies }} \times 100 \%$

2. Indeks Keanekaragaman (Index of Diversity)

Keanekaragaman spesiesdihitung menggunakan rumus indeks Shannon $\left(H^{\prime}\right)$ sebagai berikut:

$$
\bar{H}=-\sum_{\mathrm{i}=1}^{\mathrm{n}}\left(\frac{n i}{N}\right) \log \left(\frac{n i}{N}\right)
$$

Keterangan : $\quad \bar{H}=$ indeks keanekaragaman spesies

ke-i

$$
n i=\text { nilai kepentingan untuk tiap spesies atau INP spesies }
$$

$$
\begin{aligned}
& N=\text { nilai kepentingan total atau total INP } \\
& P i=\text { peluang kepentingan untuk tiap spesies }=n i / N
\end{aligned}
$$

3. Indeks Dominansi Jenis (C) (Indriyanto, 2006).

Indeks dominansi suatu spesies, dihitung menggunakan rumus sebagai berikut:

$$
C=\sum_{i=1}^{n}(n i / N)^{2}
$$

Keterangan :

$\mathrm{C}=$ Indeks dominansi jenis

$n i \quad=$ Nilai kepentingan untuk tiap spesies atau INP spesies ke- $\mathrm{i}$

$N=$ Total nilai kepentingan atau total INP

4. Indeks Kekayaan Spesies (RI)

Kekayaan spesies dihitungmenggunakanindeks Margalief (Ludwig dan Reynold, 1988), yaitu:

$$
\mathrm{RI}=\underline{(S-1)}
$$

Komposisi Jenis Vegetasi Penyusun Hutan Mangrove Di Desa Nipah Panjang Kabupaten Kubu Raya

NT - Iumlnh totolindividn 
5. Indeks Kemerataan Spesies (E) (Odum, 1993).

Indeks kemerataan spesies dihitung menggunakan rumus

$$
\begin{array}{ll}
\mathrm{E}=\frac{\mathrm{H}^{\prime}}{\mathrm{In}(\mathrm{S})} & \\
\text { Keterangan : } & \mathrm{E}=\text { Indeks Kemerataan spesies } \\
& \mathrm{H}^{\prime}=\text { Indeks Keanekaragaman spesies } \\
\mathrm{S}=\text { Jumlah spesies }
\end{array}
$$

HASIL DAN PEMBAHASAN

\section{A. Struktur Vegetasi Hutan \\ Mangrove Desa Nipah Panjang}

Struktur vegetasi suatu hutan sangat dipengaruhi oleh kerapatan suatu tegakan. Kerapatan tegakan dapat diartikan sebagai jumlah individu pohon per satuan luas. Struktur vegetasi suatu hutan dapat dikatakan normal apabila membentukan suatu kurva "J" terbalik (Hidayat, 2014). Struktur vegetasi hutan terbentuk dari hasil proses biofisika dan dinamika hutan untuk menggambarkan keanekaragaman dan fungsi suatu ekosistem (Spies, 1998). Jumlah pohon dan struktur vegetasi hutan dapat menggambarkan tingkat ketersediaan tegakan pada setiap tingkat pertumbuhan (Muhdin et al, 2008). Struktur vegetasi hutan mangrove di Desa Nipah Panjang dapat dilihat pada Gambar 2.

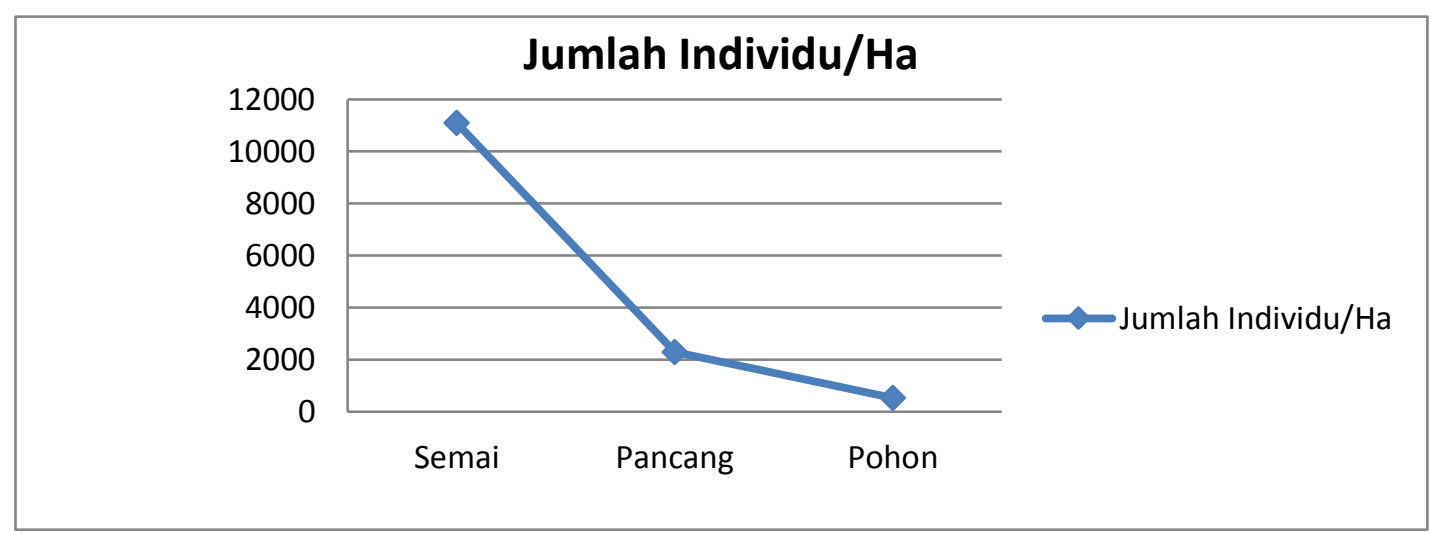

Gambar 2. Struktur Vegetasi Hutan Mangrove Desa Nipah Panjang

Kerapatan rata-rata pohon di pertumbuhan pohon. Jumlah individu lokasi penelitian mengalami pada tingkat semai berjumlah penurunan secara eksponensial 11.100/ha, jumlah individu pada seiring dengan semakin tingkat pertumbuhan pancang bertambahnya diameter dan tingkat berjumlah 2.288 /ha, sedangkan pada 
Di Desa Nipah Panjang Kabupaten Kubu Raya

tingkat pertumbuhan pohon vegetasi tersebut umumnya dijumpai
berjumlah 530 individu/ha. Hal ini pada hutan tropis yang menunjukkan bahwa tegakan pada menggambarkan komunitas hutan lokasi penelitian cenderung tidak yang dinamis (Hidayat, 2014).

seumur. Struktur vegetasi di lokasi penelitian membentuk kurva huruf $\mathbf{J}$ terbalik, hal ini dapat menjadi indikator bahwa ketersediaan pohon muda di lokasi penelitian yang sangat dominan dan mengindikasikan bahwa hutan tersebut tergolong normal (Astiani, 2016).

Ketersediaan tegakan pada hutan bertipe normal sangat tinggi sehingga dapat memperbaiki struktur dan komposisi hutan serta dapat menjamin kelangsungan tegakan dimasa mendatang. Kehilangan pohon yang berdiameter besar dimasa mendatang akibat kerusakan atau kematian akan dapat digantikan oleh pohon yang berdiameter lebih

\section{B. Indeks Nilai Penting (INP)} Indeks nilai penting (INP) jenis tumbuhan pada suatu komunitas merupakan salah satu parameter yang menunjukkan peranan jenis tumbuhan tersebut dalam komunitasnya. Peranan suatu jenis dalam komunitas dapat dilihat dari besarnya nilai INP. Jenis dengan nilai INP tertinggi merupakan jenis yang mendominasi di komunitasnya, sehingga dengan melihat nilai INP suatu jenis, maka dapat diketahui pula jenis apa saja yang mendominasi pada suatu tegakan hutan. Nilai INP dari keseluruhan sub-petak penelitian dapat lihat pada Tabel 1. 
Komposisi Jenis Vegetasi Penyusun Hutan Mangrove

Di Desa Nipah Panjang Kabupaten Kubu Raya

Tabel 1. Jumlah Individu dan Nilai INP Jenis Vegetasi Tingkat Semai, Pancang dan Pohon.

\begin{tabular}{|c|c|c|c|c|c|c|c|}
\hline \multirow{3}{*}{ No } & \multirow{3}{*}{ Nama Ilmiah } & \multicolumn{6}{|c|}{ Tingakat Pertumbuhan } \\
\hline & & \multicolumn{2}{|c|}{ Semai } & \multicolumn{2}{|c|}{ Pancang } & \multicolumn{2}{|c|}{ Pohon } \\
\hline & & $\begin{array}{c}\sum \text { Ind } \\
\text { /ha }\end{array}$ & INP\% & $\sum$ Ind /ha & INP\% & $\sum$ Ind /ha & INP\% \\
\hline 1 & Avicennia alba & 2.500 & 32,26 & 400 & 48,18 & 62 & 31,69 \\
\hline 2 & Avicennia marina & 450 & 12,9 & - & - & 12 & 5,17 \\
\hline 3 & $\begin{array}{l}\text { Bruguiera } \\
\text { gymnorrhiza }\end{array}$ & 1.750 & 22,58 & 456 & 70,46 & 138 & 91,39 \\
\hline 4 & Exoecaria agallocha & 400 & 12,9 & 224 & 24,73 & 64 & 38,32 \\
\hline 5 & $\begin{array}{l}\text { Rhizhopora } \\
\text { apiculata }\end{array}$ & 1.950 & 38,71 & 344 & 40,82 & 90 & 48,55 \\
\hline 6 & $\begin{array}{l}\text { Rhizophora } \\
\text { mucronata }\end{array}$ & 2.200 & 41,94 & 208 & 26,04 & 66 & 36,48 \\
\hline 7 & Sonneratia alba & 650 & 19,35 & 392 & 52,83 & 48 & 23,37 \\
\hline 8 & $\begin{array}{l}\text { Xylocarpus } \\
\text { moluccencis }\end{array}$ & 1.200 & 19,35 & 264 & 36,94 & 50 & 25,03 \\
\hline & Jumlah & 11.100 & 200 & 2.288 & 300 & 530 & 300 \\
\hline
\end{tabular}

Sumber: Hasil Analisis Data Lapangan, 2020.

Tabel 1 menunjukkan bahwa

nilai INP tertinggi untuk tingkat semai adalah jenis Rhizophora mucronata dengan nilai INP sebesar $41,94 \%$, pada tingkat pertumbuhan pancang nilai INP tertinggi adalah jenis Sonneratia alba dengan nilai INP sebesar 52,83\% dan pada tingkat pertumbuhan pohon nilai INP tertinggi terdapat pada jenis Bruguiera gymnorrhiza dengan nilai INP sebesar 91,39\%. Jika dibandingkan hasil penelitian penulis dengan hasil penelitian Nasir et al,
(2019) terdapat kesamaan jenis vegetasi tingkat semai dan tingkat pohon yang memiliki nilai INP tertinggi, dimana tingkat semai adalah jenis Rhizophora mucronata dengan nilai INP sebesar 28,57\% dan tingkat pohon adalah jenis Bruguiera gymnorrhiza dengan nilai sebesar $53,49 \%$.

Sukarna (2013) menyebutkan jenis yang mendominasi suatu areal dinyatakan sebagaijenis yang memiliki kemampuan adaptasi dan toleransi yang lebar terhadap kondisi 
Komposisi Jenis Vegetasi Penyusun Hutan Mangrove

Di Desa Nipah Panjang Kabupaten Kubu Raya

lingkungan. Suatu spesies dianggap dominan diindikasikan oleh indeks nilai penting, yaitu mempunyai nilai frekuensi, densitas dan dominansi lebih tinggi dibanding spesies lain. Indeks nilai penting suatu jenis memberikan gambaran bahwa keberadaan jenis tersebut semakin stabil atau berpeluan guntuk dapat mempertahankan pertumbuhan dan kelestarian jenisnya. Suatu jenis tingkat semai bisa dikatakan berperan apabila memiliki INP > $10 \%$, sedangkan pada tingkat pancang dan pohon bisa dikatakan berperan apabila nilai INP > 15\%

(Ferianita, 2006; Mawazin dan Subiakto, 2013).

\section{Indeks Dominansi Jenis (C)}

Indeks dominansi jenis (C) merupakan suatu parameter yang dapat digunakan dalam suatu komunitas untuk menyatakan tingkat terpusatnya dominansi suatu spesies (Prastomo et al, 2017). Hasil analisis indeks dominansi jenis (C) vegetasi tingkat semai, pancang, dan pohon dapat dilihat pada Tabel 2.

Tabel 2. Rekapitulasi Indeks Dominansi Jenis (C) Semai, Pancang dan Pohon

\begin{tabular}{llccc}
\hline \multirow{2}{*}{ No } & \multirow{2}{*}{ Nama Ilmiah } & \multicolumn{2}{c}{ Indeks Dominansi Jenis (C) } \\
\cline { 3 - 5 } & & Semai & Pancang & Pohon \\
\hline 1 & Avicennia alba & 0,007799 & 0,001527 & 0,00096 \\
2 & Avicennia marina & 0,000229 & - & 0,00003 \\
3 & Bruguiera gymnorrhiza & 0,003788 & 0,003852 & 0,00438 \\
4 & Exoecaria agallocha & 0,000178 & 0,000639 & 0,00155 \\
5 & Rhizhopora apiculata & 0,004717 & 0,001297 & 0,00169 \\
6 & Rhizophora mucronata & 0,006022 & 0,000803 & 0,0013 \\
7 & Sonneratia alba & 0,000497 & 0,002184 & 0,00059 \\
8 & Xylocarpus moluccencis & 0,001757 & 0,001527 & 0,00067 \\
\hline
\end{tabular}

Sumber: Hasil analisis data lapangan, 2020.

Tabel 2 dapat dilihat bahwa jenis vegetasi tingkat semai yang memiliki nilai $\mathrm{C}$ tertinggi adalah jenis Rhizophora mucronata dengan nilai $\mathrm{C}=0,006022$, pada tingkat pancang jenis Bruguiera gymnorrhiza dengan nilai $\mathrm{C}=0,003852$ dan pada tingkat pohon terdapat pada jenis Bruguiera gymnorrhiza dengan nilai 
Di Desa Nipah Panjang Kabupaten Kubu Raya

$\mathrm{C}=0,00438$. Hutan mangrove Desa

Nipah Panjang tidak dikuasai oleh satu jenis apapun, melainkan cenderung mendominasi secara bersama-sama. Hal ini sesuai dengan pendapat Indiyanto (2006) bahwa nilai $\mathrm{C}$ mendekati nilai 0 (nol) atau rendah. Hasil penelitian Nasir et al, (2019) bahwa nilai C hutan mangrove di Desa Medan Mas tergolong rendah dan tidak dikuasai oleh satu jenispun melainkan mendominasi secara bersama-sama karena memiliki nilai $\mathrm{C}$ mendekati 0 (nol).

\section{Indeks}

Keanekaragaman

\section{Jenis $\left(\mathbf{H}^{\prime}\right)$}

Indeks keanekaragaman jenis merupakan suatu nilai yang menunjukkan keberagaman jenis yang ditemukan di lapangan. Semakin tinggi nilai indeks keanekaragaman jenis $\left(\mathrm{H}^{\prime}\right)$, maka semakin banyak jenis-jenis yang terdapat pada kawasan tersebut. Data hasil perhitungan nilai indeks keanekaragaman jenis $\left(\mathrm{H}^{\prime}\right)$ di hutan mangrove Desa Nipah Panjang dapat dilihat pada Tabel 3.

Tabel 3. Rekapitulasi Indeks Keanekaragaman Jenis (H') Semai, Pancang dan Pohon

\begin{tabular}{llccc}
\hline \multirow{2}{*}{ No } & \multirow{2}{*}{ Nama Ilmiah } & \multicolumn{3}{c}{ Indeks Keanekaragaman Jenis (H') } \\
\cline { 3 - 5 } & & Semai & Pancang & Pohon \\
\hline 1 & Avicennia alba & 0,203549 & 0,202231 & 0,10821 \\
2 & Avicennia marina & 0,0542 & - & 0,009778 \\
3 & Bruguiera gymnorrhiza & 0,119185 & 0,373271 & 0,5901 \\
4 & Exoecaria agallocha & 0,0542 & 0,076037 & 0,142919 \\
5 & Rhizhopora apiculata & 0,271376 & 0,15709 & 0,204619 \\
6 & Rhizophora mucronata & 0,309054 & 0,08177 & 0,132887 \\
7 & Sonneratia alba & 0,095415 & 0,233481 & 0,070288 \\
8 & Xylocarpus moluccencis & 0,095415 & 0,135365 & 0,077332 \\
\hline & Total Jumlah $\left(\mathbf{H}^{\prime}\right)$ & $\mathbf{1 , 2 0 2 3 9 4}$ & $\mathbf{1 , 2 5 9 2 4 5}$ & $\mathbf{1 , 3 3 6 1 3 3}$
\end{tabular}

Sumber: Hasil analisis data lapangan, 2020.

Hasil analisis sebagaimana ditampilkan pada Tebel 3 menunjukkan bahwa nilai $\mathrm{H}^{\prime}$ pada tingkat semai, pancang dan pohon berada pada angkat $>1$. Angka ini menunjukkan bahwa di lokasi 
Komposisi Jenis Vegetasi Penyusun Hutan Mangrove

Di Desa Nipah Panjang Kabupaten Kubu Raya

penelitian keanekaragaman jenis vegetasi di wilayah tersebut tergolong sedang. Hal ini sesuai dengan pendapat Ferianita (2007) kisaran indeks keanekaragaman jenis $\left(\mathrm{H}^{\prime}\right)$ antara 1-3. Kisaran nilai $\mathrm{H}^{\prime}<1$ berarti keanekaragaman rendah, jika H' $1-<3$ berarti keanekaragaman sedang dan jika $\mathrm{H}^{\prime}>3$ berarti keanekaragaman tinggi. Faktor yang dapat mempengaruhi keanekaragaman spesies tumbuhan pada suatu kawasan yaitu: bahan organik tanah, kelengasan tanah, ph E. Indeks Kemerataan Jenis (E) Indeks kemerataan jenis (E) dipengaruhi oleh besarnya nilai keanekaragaman suatu jenis dan jumlah seluruh jenis. Artinya semakin tinggi nilai kelimpahan jenis maka penyebaran suatu jenis semakin merata dalam suatu kawasan, begitu pula sebaliknya. Hasil penghitungan indeks kemerataan jenis di hutan mangrove Desa Nipah Panjang dapat dilihat pada Tabel 4 .

tanah, suhu, dan intensitas cahaya

(Kusmana dan Susanti, 2014).

Tabel 4. Rekapitulasi Indeks Kemerataan Jenis (E) Semai, Pancang dan Pohon

\begin{tabular}{clccc}
\hline \multirow{2}{*}{ No } & \multirow{2}{*}{ Nama Ilmiah } & \multicolumn{2}{c}{ Indeks Keanekaragaman Jenis (H') } \\
\cline { 3 - 5 } & & Semai & Pancang & Pohon \\
\hline 1 & Avicennia alba & 0,173072 & 0,202231 & 0,113399 \\
2 & Avicennia marina & 0,046085 & - & 0,010247 \\
3 & Bruguiera gymnorrhiza & 0,10134 & 0,373271 & 0,618397 \\
4 & Exoecaria agallocha & 0,046085 & 0,076037 & 0,149773 \\
5 & Rhizhopora apiculata & 0,230744 & 0,15709 & 0,214431 \\
6 & Rhizophora mucronata & 0,262781 & 0,08177 & 0,139259 \\
7 & Sonneratia alba & 0,081129 & 0,233481 & 0,073658 \\
8 & Xylocarpus moluccencis & 0,081129 & 0,135365 & 0,08104 \\
\hline & Total Jumlah $(\mathbf{E})$ & $\mathbf{1 , 0 2 2 3 6 6}$ & $\mathbf{1 , 2 5 9 2 4 4}$ & $\mathbf{1 , 4 0 0 2 0 4}$
\end{tabular}

Sumber: Hasil analisis data lapangan, 2020

Hasil analisis kemerataan jenis pada Tabel 4 menunjukkan bahwa lokasi hutan mangrove di Desa
Nipah Panjang pada tingkat semai, pancang dan pohon masuk dalam katagori tidak merata karena 
memiliki nilai $\mathrm{E}>1$. Hal ini sesuai dengan pendapat Odum (1993) bahwa indeks kemerataan jenis (E) berkisar antara 0-1, jika $\mathrm{E}>1$, maka seluruh jenis yang ada memiliki kelimpahan yang tidak merata, sedangkan jika $E<1$, maka seluruh jenis yang ada kelimpahan merata. Menurut Prastomo et al (2017) nilai kelimpahan yang tidak merata menunjukkan bahwa dalam setiap sub-petak penelitian yang diamati, tidak setiap petak selalu memiliki jenis yang sama.

\section{F. Indeks Kekayaan Jenis (RI)}

Indeks kekayaan jenis adalah indeks yang menunjukan kekayaan jenis dalam suatu komunitas. Besarnya nilai kekayaan spesies dapat dipengaruhi oleh banyaknya jumlah spesies/jenis dan jumlah individu dalam suatu komunitas. Nilai indeks kekayaan dapat dihitung berdasarkan tingkat pertumbuhan mulai dari semai, pancang dan pohon. Hasil penghitungan indeks kekayaan jenis di hutan mangrove Desa Nipah Panjang Kecamatan Batu Ampar dapat dilihat pada Tabel 5.

Tabel 5. Rekapitulasi Indeks Kekayaan Jenis (RI) Semai, Pancang dan Pohon

\begin{tabular}{clc}
\hline No & \multicolumn{1}{c}{ Tingkat Pertumbuhan } & Indeks Kekayaan Jenis (RI) \\
\hline 1 & Semai & 3,04 \\
2 & Pancang & 2,42 \\
3 & Pohon & 2,88 \\
\hline
\end{tabular}

Sumber: Hasil analisis data lapangan, 2020

Tabel 5 menunjukkan bahwa terdapat perbedaan nilai kekayaan jenis yang terdapat di hutan mangrove Desa Nipah Panjang. Tingkat pertumbuhan semai, pancang dan pohon memiliki nilai $<3,5$. Hasil ini menunjukkan bahwa kekayaan jenis di hutan mangrove Desa Nipah Panjang tergolong rendah. Hal ini sejalan dengan pendapat Magurran
(1988) besaran indeks kekayaan spesies (RI) apabila nilai < 3,5 menunjukan kekayaan jenis tergolong rendah, apabila nilai $>3,5$ - 5,0 tergolong sedang, apabila nilai $>$ 5,0 menunjukan kekayaan jenis tergolong tinggi.

Indeks kekayaan jenis sangat berperan dalam menentukan nilai keanekaragaman jenis. Hal ini 
Di Desa Nipah Panjang Kabupaten Kubu Raya

disebutkan Wijana (2014) bahwa keanekaragaman jenis dipengaruhi oleh nilai kemerataan jenis (E) dan kekayaan jenis (RI) dan diantara kedua komponen tersebut, masingmasing memiliki indeks tertentu. Nilai indeks kekayaan jenis sama atau mendekati sama, maka antara kemerataan jenis dan kekayaan jenis yang menentukan indeks keanekaragaman memiliki kontribusi yang sama atau seimbang dan apabila hal itu terjadi sebaliknya, maka salah satu komponen memberikan kontribusi yang lebih besar.

\section{PENUTUP}

\section{Kesimpulan}

1. Jumlah jenis yang ditemukan pada tingkat semai berjumlah 8 jenis dengan jumlah individu sebesar 11.100 individu/ha, pada tingkat pancang ditemukan sebanyak 7 jenis dengan jumlah individu sebesar 2.288 individu/ha, pada tingkat pohon ditemukan sebanyak 8 jenis dengan jumlah individu sebesar 530 individu/ha.

2. INP tertinggi tingkat semai jenis Rhizophora mucronata dengan nilai INP sebesar 41,94\%, pada tingkat pertumbuhan pancang nilai INP tertinggi adalah jenis Sonneratia alba dengan nilai INP sebesar 52,83\% dan pada tingkat pertumbuhan pohon nilai INP tertinggi terdapat pada jenis Bruguiera gymnorrhiza dengan nilai INP sebesar 91,39\%.

3. Indeks dominansi (C) tertinggi tingkat semai jenis Rhizophora mucronata dengan nilai $\mathrm{C}=0,006022$, pada tingkat pancang jenis Bruguiera gymnorrhiza dengan nilai $\mathrm{C}=0,003852$ dan pada tingkat pohon terdapat pada jenis Bruguiera gymnorrhiza dengan nilai $\mathrm{C}=0,00438$.

4. Indeks keanekaragaman jenis (H) pada tingkat semai, pancang dan pohon tergolong sedang dengan nilai $>1$.

5. Indeks kemerataan (E) pada tingkat semai, pancang dan pohon masuk dalam katagori tidak merata dengan nilai $\mathrm{E}>1$.

6. Indeks kekayaan jenis (RI) tingkat pertumbuhan semai, pancang dan pohon tergolong rendah dengan nilai $<3,5$.

\section{Saran}

Hutan mangrove di Desa Nipah Panjang perlu dijaga kelestariannya, agar jenis-jenis tanaman yang tumbuh di lokasi tersebut dapat terjamin kelangsungan hidupnya. Dengan menjaga keutuhan hutan 
Komposisi Jenis Vegetasi Penyusun Hutan Mangrove

Di Desa Nipah Panjang Kabupaten Kubu Raya

mangrove, maka dapat menjaga

ekosistem yang ada di atasnya.

\section{DAFTAR PUSTAKA}

Astiani D. 2016. Tropical Peatland Tree-Species Diversity Altered by Forest Degradation. Jurnal Biodiversitas. 17 (01) : 102109.

Ferianita M. 2006. Metode Sampling Bioekologi. Penerbit PT Bumi Aksara. Jakarta.

Hidayat S. 2014. Kondisi Vegetasi Hutan Lindung Sesaot, Kabupaten Lombok Barat, Nusa Tenggara Barat, Sebagai Informasi Dasar Pengelolaan Kawasan. Jurnal Penelitian Kehutanan Wallacaea 3 (2): 97-105.

Indriyanto. 2006. Ekologi Hutan. Jakarta: Penerbit PT Bumi Aksara.

Kusmana C, Susanti S. 2014. Komposisi dan Struktur Tegakan Hutan Alam di Hutan Pendidikan Gunung Walat Jawa Barat. Jurnal Silvikultur Tropika. 5 (03): 210-217.

Ludwiq, J. A. and J. F. Reynolds. 1988. Statistical Ecology a Primer on Methods and Computing, John Wiley \& Sons, New York.

Mawazin, Subiakto A. 2013. Keanekaragaman dan Komposisi Jenis Permudaan Alam Hutan Rawa Gambut
Bekas Tebangan di Riau. Jurnal Indonesian Forest Rehabilitation 1 (01) : 59-73.

Nasir M, Burhanuddin, Dewantara I. 2019. Keanekaragaman Jenis Vegetasi Penyusun Hutan Mangrove Di Desa Medan Mas Kabupaten Kubu Raya. Jurnal Hutan Lestari. 7 (02): $973-982$.

Odum E. 1993. Dasar-Dasar Ekologi. Terjemahan Oleh Tjahjono Samingan Dari Buku Fundamentals Of Ecology. Yogyakarta: Gajah Mada University Press.

Prastomo RH, Herawatiningsih R, Latifah $\quad$ S. 2017. Keanekaragaman Vegetasi di Kawasan Hutan Mngrove Desa Nusapati Kabupaten Mempawah. Jurnal Hutan Lestari 5 (2) : 556 - 562.

Pratama BA, Alhamd L, Rahajoe JS. 2012. Asosiasi dan Karakterisasi Tegakan pada Hutan Rawa Gambut di Hampangen, Kalimantan Tengah. J. Tek. Ling : 69-76.

Rahmawati D, Setyobudiandi I, Hilmi E. 2014. Potensi Estimasi Karbon Tersimpan Pada Vegetasi Mangrove di Wilayah Pesisir Muara Gembong Kabupaten Bekasi. Jurnal Omni-Akuatika 13 (19) : 85-91.

Spies TA. 1998. Forest Structure: A Key To The Ecosystem. Northwest Science 72 (2) : 34-39. 
Komposisi Jenis Vegetasi Penyusun Hutan Mangrove

Di Desa Nipah Panjang Kabupaten Kubu Raya

\begin{tabular}{crrrr}
\hline Sukarna RM. 2013. & Perubahan & Tengah. Jurnal & Ilmu \\
Struktur dan & Komposisi & Kehutanan 7 (02): 129 -146. \\
Hutan Rawa & Gambut & & \\
Menggunakan & Citra & Suryono A. 2013. Sukses Usaha \\
Penginderaan Jauh Dan & Pembibitan Mangrove Sang \\
Pendekatan Ekologis Di & Penyelamat Pulau. Penerbit \\
Kawasan & Bekas & Pustaka & Baru \\
Pengembangan & Lahan & Bantul. Yogyakarta.
\end{tabular}

Gambut Provinsi Kalimantan 